\title{
Relationship between Certification to Professional Competency of Kindergarten Teacher in Nanggalo, Padang
}

\author{
Indra Jaya \\ Early childhood education department \\ Universitas Negeri Padang, Indonesia \\ indrajaya@fip.unp.ac.id
}

\begin{abstract}
The research objective was to determine the relationship of teacher certification for professional competence kindergarten in Nanggalo District of Padang. This study uses quantitative methods correlations. Respondents are excepting a kindergarten teacher in the district of Padang Nanggalo numbered 13 people. The data analysis technique is a description of the data and data analysis correlation. The results showed: (1) the professional competence of teachers appear to be low it can be seen from the number of respondents who chose alternative Rarely showing the highest rates. (2) Certification of teachers seem low, it is seen rarely and never showed the highest rate. (3) There is a significant correlation between teacher certification with the professional competence of teachers.
\end{abstract}

Keywords: certification, teacher's profesional competence

\section{INTRODUCTION}

Early childhood is an individual figure as a sociocultural being who is experiencing a certain number of characteristics, early childhood experiences a fundamental developmental process in the sense that developmental experiences at this time can provide longlasting effects so as to underlie the process of further child development.

Achieving the above goals is needed by a teacher who is a professional teacher. Teachers are a very dominant component of education in improving the quality of education. This is because the teacher is a person who is directly involved in the learning process. For the quality of the learning process, the teacher must also be qualified and professional. Professional teachers have special abilities and expertise in the field of teacher training, so that they are able to perform their duties and functions as teachers with maximum abilities. In addition, teachers are very closely related to the quality of graduates. Therefore, the profession of teacher resources needs to continue to grow and develop in order to be able to perform its functions professionally. The way to develop the ability of teacher resources is to improve teacher competence.

Educator certificates are formal proof of professionalism, while teacher certification is a process of recognizing that a person has the competence to carry out educational services to certain educational units after passing the competency test conducted by the certified institutions. So teacher certification is a process of competency testing designed to reveal mastery of competencies designed to express mastery of one's competencies as a basis for providing educator certificates. The following are data on certification teachers in Nanggalo, Padang. The phenomena encountered in several kindergartens show that 1) Some teachers are less able to plan learning and carry out learning in carrying out the teaching and learning process, such as in delivering teaching still teaching and not directing, 2) the media used is less varied 3) teachers in implementing learning are less successful, this shows the low learning outcomes achieved by children, 4) lack of teachers' ability to master teaching material or materials, 5) some teachers are less creative in managing learning programs, 6) teachers rarely carry out evaluations from each learning process.

The purpose of this study was to determine the relationship of teacher certification to the professional competencies in Kindergarten in Nanggalo District, Padang. The teacher is a professional profession where they are required to make every effort to carry out their profession as best they can. As a professional, the task of the teacher as an educator, teacher and trainer should be able to impact the students. In this case the teacher should be able to continuously improve its performance which is the capital for educational success. Competence is the ability and authority of the teacher in carrying out his teaching profession. The word "professional" comes from adjectives which mean livelihood and as a noun which means people who have expertise such as teachers, doctors, judges, and so on. In other words, professional work is work that can only be done by those who are specially prepared for it and not the work carried out by those who cannot obtain other jobs (Usman, 2008: 14).

By pointing to this definition, the definition of professional teachers is people who have the ability and special expertise in the field of teacher training so that they are able to perform their duties and functions as teachers with maximum abilities. In other words professional teachers are well-educated and well-trained people, and have rich experience in their fields (Usman, 2008: 15). What is meant by being educated and trained is not only getting formal education but also having to master the educational foundations.

The following is quoted from Muslich (2007: 2) there are several articles contained in the Law of the 
Republic of Indonesia Number 14 of 2005 concerning Teachers and Lecturers as follows: Article 1 point 11: Certification is the process of giving educator certificates to teachers and lecturers 2) Article 8 : Teachers must have academic qualifications, competence, education certification, physical and spiritual health, and have the ability to realize national education goals Article 16: Teachers who have an educator certificate receive a professional allowance of one salary, public and private teachers paid by the government.

Teachers have a strategic role in the field of education, even other educational resources that are adequate are often insignificant if not accompanied by adequate teacher quality. Likewise, the opposite happens, if the quality teacher is less supported by other adequate supporting resources, it can also cause less optimal performance.

Certification is the process of providing educator certificates for Teachers and Lecturers. In the perspective of Law No. 14 of 2005 concerning Teachers and Lecturers, they are called educator certificates. The educator in question is the teacher. The process of providing educator certificates for teachers is called Teacher certification. Educator certificates are given to Teachers who have met Teacher's professional standards. Professional teachers are an absolute requirement to create a quality education system and practice. Certification is one of the efforts made by the government so that Teachers in various regions in the country can work professionally by collecting various file portfolios consisting of evidence of achievements, performance results and various matters related to the teacher's work. Certification based on the Teacher's portfolio in positions with qualifications as specified in Article 2 paragraph (3) of the Ministry of National Education Number 18 of 2007 concerning Certification for Occupational Teachers, consisting of: Academic Qualifications; Education and training; Teaching experience; Planning and implementing learning; Assessment of supervisors and supervisors; Academic achievement; Professional development works participating in scientific forums; Experience of organizations in the education and social fields; and awards relevant to the field of education.

The main objective of certification is to guarantee the quality of teachers so that the professionalization of teachers can run well. Mulyasa (2011), in essence the teacher certification is to get good teachers and professionals who have the competence to carry out the functions and objectives of particular schools, as well as national education goals in general according to the needs of the community and the demands of the times. In essence, teacher certification is to get good teachers and professionals who have the competence to carry out the functions and objectives of schools in particular, as well as national education goals in general according to the needs of the community.

Through Teacher certification, according to Permadi (2010: 61) besides increasing the competence and professionalism of the Teachers, it also influences the improvement of Teacher's welfare through increasing Teacher's salary. The thing that lies behind the existence of Teacher certification is to improve the quality of education in Indonesia.

The quality of teacher professionalism that is expected to be realized from teacher certification is the increased competency required to carry out education and teaching tasks both personality competencies, learning management competencies of students, mastery of subject matter competencies, and social or communication skills and interact efficiently and efficiently with students (Dirjen Dikti and Director General of PMPTK Ministry of Education, 2005)

Teacher certification policies will be able to realize or enhance teacher professionalism. Therefore, the effectiveness of teacher certification policies will be demonstrated by the extent to which teacher professionalism can be realized or become more favorable and the demands of the times.

\section{METHOD}

This research was conducted using quantitative correlational methods, Irianto (2004: 133) states that correlational research methods are used to determine the relationship between one variable and another variable. While to find out the size of the contribution of independent variables to the dependent variable calculation is needed in the form of a correlation coefficient. The study was conducted in OctoberNovember 2015, which was located in the Kindergarten of Nanggalo District, Padang City. The population of this study was all kindergarten teachers in Naggalo SubDistrict, Padang City who had been certified, totaling 13 people. The sampling technique using the census method is to take the total number of population as sampe as many as 13 people.

The data collection tool used in this study is indirect communication techniques. In this case the tool used is a questionnaire (questionnaire) distributed to respondents. Then it is filled directly by the respondent in question, each choice that has been provided for each statement. The data collection technique used in this study is a closed questionnaire, which has been prepared in accordance with the research variables to be given to the respondents. Data analysis techniques in this study are data descriptions and correlational data analysis (product moment).

\section{RESULT AND DISCUSSION}

\section{Result}

The results of the research are an overview of teacher professional competencies. It can be seen that as many as $11.55 \%$ of respondents answered Always alternatives. The respondents who answered often alternatives were $13.24 \%$. Whereas those who answered Sometimes alternatives were $26.56 \%$. Only $39.86 \%$ answered in rare alternatives, and those who answered Never were $8.86 \%$.

Thus it can be concluded that according to the researcher the description of the data on the professional competence of the Kindergarten teachers in Nanggalo, Padang seems to be low, as seen from the number of respondents who answered alternative answers Occasionally and rarely as many as $66.42 \%$. 
The results of the study illustrate that teacher certification shows that as many as $14.36 \%$ of respondents answered Always alternatives. The respondents who answered the Frequent alternative were $16.32 \%$. Whereas those who answered Occasional alternatives were $46.33 \%$. Only $13.53 \%$ answered on rare alternatives, and those who answered Never were $9.63 \%$.

Thus it can be concluded that according to the researcher the description of the data on the certification of kindergarten teachers in Nanggalo, Padang is seen to be lacking this can be seen from the number of respondents who answered alternative answers Sometimes and rarely as many as $59.86 \%$.

Based on the processing of data obtained $\mathrm{r}$ count $=$ 0.728 and the value is consulted with the value of $r$ table $=0.553$ with $\mathrm{n}=13$. From the results of the consultation, the $r$ count is greater than $r$ table ( $r$ count $>r$ table), both at a significant level of $95 \%$ (0.728). If the value of $r$ count is greater than $\mathrm{r}$ table then $\mathrm{H} 0$ is rejected and vice versa $\mathrm{H} 1$ is accepted. Thus there is a significant relationship between the certification of teachers and the professional competencies of kindergarten teachers in Naggalo Subdistrict. This means that if teacher certification is high, the professional competence of teachers will be better. So it can be concluded that with good teacher certification, the professional competence of teachers will also be better.

\section{Discussion}

In accordance with the results of the research in the previous section "There is a significant relationship between certification and the professional competence of the Kindergarten Teachers in Nanggalo". To be more convincing about the findings of this study, there are several things that need to be discussed further, namely: The findings of the study indicate that the picture of teacher professional competence seems low, this is indicated by the number of respondents answering rarely and never. This shows that there is still a lack of teacher certification in Nanggalo Padang Kindergarten.

Competence is the ability and authority of the teacher in carrying out his teaching profession. The word "professional" comes from adjectives which mean livelihood and as a noun which means people who have expertise such as teachers, doctors, judges, and so on. In other words, professional work is work that can only be done by those who are specially prepared for it and not the work carried out by those who cannot obtain other jobs (Usman, 2008: 14). Mulyasa (2011: 135) describes professional competence in the National Education Standards, which are listed in Article 28 paragraph (3) point $\mathrm{c}$ stated that what is meant by professional competence is the broad and profound mastery of learning material that enables students to meet specified competency standards in the National Education Standards.

Based on the expert's opinion above that professional competence can be concluded that the work performance achieved by the teacher in the learning process is good in terms of preparation, implementation, and achievement of the teacher in carrying out teaching and learning interactions in the classroom. The indicators to be measured in this study are 1) mastery of learning material, 2) mastering the standards of competency and basic competency of subjects, 3) Developing the subject matter that is taught, 4) Developing professionalism, 5) Utilizing information technology.

The research findings show that the picture of Nanggalo Padang Kindergarten teacher certification looks low which is indicated by the number of respondents answering rarely and never. The following is quoted from Muslich (2007: 2) there are several articles contained in the Law of the Republic of Indonesia Number 14 of 2005 concerning Teachers and Lecturers as follows: Article 1 point 11: Certification is the process of giving educator certificates to teachers and lecturers 2) Article 8 : Teachers must have academic qualifications, competence, education certification, physically and mentally healthy, and have the ability to realize national education goals Article 16: Teachers who have an educator certificate receive a professional allowance of one salary, public and private teachers paid by the government.

From the description of the certification above, it can be concluded that certification is in the process of giving educator certificates to teachers who have met certain requirements, namely having academic qualifications, competence, physical and spiritual health, and having the ability to realize national education goals.

These results indicate that there is a relationship between teacher certification and the professional competence of Nanggalo Padang Kindergarten teachers because of $r$ count $>r$ table. Data analysis shows that teacher certification factors contribute to the teacher's professional competence. The main objective of certification is to guarantee the quality of teachers so that the professionalization of teachers can run well. Mulyasa (2011), in essence the teacher certification is to get good teachers and professionals who have the competence to carry out the functions and objectives of particular schools, as well as national education goals in general according to the needs of the community and the demands of the times. In essence, teacher certification is to get good teachers and professionals who have the competence to carry out the functions and objectives of schools in particular, as well as national education goals in general according to the needs of the community. Through Teacher certification, according to Dadi Permadi (2010: 61) in addition to increasing the competence and professionalism of the Teachers, it also influences the improvement of Teacher's welfare through increasing Teacher salaries. The thing behind the existence of Teacher certification is to improve the quality of education in Indonesia The quality of teacher professionalism that is expected to be realized from teacher certification is the increased competency required to carry out education and teaching tasks both personality competencies, learning management competencies of students, mastery of subject matter competencies, and social or communication skills and interact efficiently and efficiently with students (Dirjen Dikti and Director General of PMPTK Ministry of Education, 2005). Teacher certification policies will be able to realize or enhance teacher professionalism. Therefore, the effectiveness of teacher certification policies will be demonstrated by the extent to which teacher 
professionalism can be realized or become more favorable and the demands of the times.

\section{CONCLUSION}

Based on the results of the research and discussion of the relationship between teacher certification and the professional competence in Nanggalo Padang Kindergarten teachers, the following conclusions were obtained: 1) The teacher's professional competency picture is low, as seen in the number of respondents who choose Rarely alternatives, which can be seen in the rare percentage "rare" shows the highest number. 2) The description of teacher certification looks less, that is, it is seen as a percentage rarely and never shows the highest number. 3) There is a significant relationship between teacher certification and the professional competence in Nanggalo Padang Kindergarten teachers.

Based on the above research, some suggestions can be given as follows: 1) It is expected that the teacher learns to be more creative in developing learning materials for children, especially in the Nanggalo Padang
Kindergarten. 2) It is hoped that the Education Office will pay more attention to teacher certification, especially in the Nanggalo Padang Kindergarten in order to increase teacher professional competence.

\section{REFERENCES}

[1] Irianto, Agus. 2004. Statistik Konsep Dasar Dan Aplikasinya. Jakarta : Prenada Media.

[2] Permadi, Dadi. 2010. The Smilling Teacher. Bandung: CV Nuansa Aulia.

[3] Depdiknas. 2010. Kurikulum Taman Kanak-kanak dan RA Standar Kompetensi. Jakarta: Depdiknas.

[4] Mulyasa. 2011. Menjadi Guru Profesional. Bandung: Remaja Rosdakarya.

[5] Husaini, Usman. 2008. Manajemen, Teori, Praktek dan Riset Pendidikan. Jakarta : Bumi Aksara.

[6] Muslich, Masnur, (2007) KTSP Pembelajaran Berbasis Kompetensi dan Kontekstual. Jakarta: PT. Bumi Angkasa

[7] Undang-Undang Nomor 14 Tahun 2005 tentang Guru dan Dosen. 